\title{
Aktivitas Ekstrak Averrhoa bilimbi, Annona squamosa, dan Tithonia diversifolia terhadap Mortalitas dan Penghambatan Pertumbuhan Larva Crocidolomia pavonana (Lepidoptera: Crambidae)
}

\author{
The Activity of Averrhoa bilimbi, Annona squamosa, and Tithonia diversifolia \\ Extracts on Mortality and Growth Inhibition of Crocidolomia pavonana \\ (Lepidoptera: Crambidae) Larvae
}

\author{
Harlina Kusuma Tuti ${ }^{1}$, Dadang ${ }^{2 *}$, dan Endang Sri Ratna ${ }^{2}$ \\ Diterima 06 April 2018/Disetujui 04 Februari 2019
}

\begin{abstract}
Crocidolomia pavonana (F.) (Lepidoptera: Crambidae) is one of the important insect pests that can reduce production of cruciferous plants. Generally farmers control this insect pest by using synthetic insecticides. However, the intensive and excessive use of synthetic insecticides may cause negative impact to the insect and environment, such as the occurence of resistance and resurgence of pests and chemical residues in agricultural products. One of alternative strategies that can be adopted to reduce the negative impact of synthetic insecticide use is by utilization of botanical insecticide. The aim of this research was to study the activities of extract Averrhoa bilimbi leaves, Annona squamosa seeds, and Tithonia diversifolia flowers on mortality and growth inhibition of C. pavonana larvae. The mortality activity was assessed by single and extract mixture using leaf residual method. The larval growth inhibition activity was also tested by using leaf residual method. A. squamosa extract at concentration of $0.015 \%$ could kill $100 \%$ of larvae at 72 hours after treatment (HAT). Meanwhile, $\underline{T}$. diversifolia extract at 5\% could kill 88\% of larvae at 144 HAT. Extract mixtures of $\underline{\text { T. diversifolia and }}$ A. squamosa at ratios 1:1, 1:2 and 2:1 (w/w) gave low mortality activity. These three extract showed growth inhibition activity against the larvae of $\underline{C}$. pavonana.
\end{abstract}

Keywords: Botanical insecticides, cabbage pest, extract mixture, toxicity

\begin{abstract}
ABSTRAK
Crocidolomia pavonana (F.) (Lepidoptera: Crambidae) merupakan salah satu hama penting yang dapat menurunkan produksi tanaman kubis-kubisan. Petani umumnya mengendalikan serangan hama ini dengan menggunakan insektisida sintetik. Namun, penggunaan insektisida sintetik yang terus-menerus dan berlebihan dapat menyebabkan dampak negatif pada serangga dan lingkungan seperti terjadinya resistensi dan resurjensi hama serta residu pada produk pertanian. Salah satu strategi alternatif yang dapat dilakukan untuk mengurangi dampak negatif penggunaan insektisida sintetik adalah dengan memanfaatkan insektisida nabati. Penelitian ini dilakukan untuk mengetahui aktivitas ekstrak daun Averrhoa bilimbi, biji Annona squamosa, dan bunga Tithonia diversifolia terhadap mortalitas dan penghambatan pertumbuhan larva $C$. pavonana. Aktivitas mortalitas diuji dengan ekstrak tunggal dan campuran menggunakan metode residu pada daun. Aktivitas penghambatan pertumbuhan larva $C$. pavonana juga diuji dengan metode residu pada daun. Ekstrak A. squamosa pada konsentrasi $0.015 \%$ dapat mematikan larva C. pavonana sebesar $100 \%$ pada pengamatan 72 jam setelah perlakuan (JSP). Sementara itu, ekstrak T. diversifolia pada konsentrasi 5\% mampu mematikan 88\% larva pada pengamatan 144 JSP. Ekstrak campuran T. diversifolia dan A. squamosa pada rasio
\end{abstract}

\footnotetext{
${ }^{1}$ Mahasiswa Departemen Proteksi Tanaman, Fakultas Pertanian, Institut Pertanian Bogor Jl. Kamper Kampus IPB Darmaga 16680, Indonesia

${ }^{2}$ Departemen Proteksi Tanaman, Fakultas Pertanian, Institut Pertanian Bogor

Jl. Kamper Kampus IPB Darmaga 16680, Indonesia

E-mail : dadangtea@ipb.ac.id (*Penulis korespondensi)
} 
1:1, 1:2, dan 2:1 (w/w) memberikan aktivitas mortalitas rendah. Ketiga ekstrak ini menunjukkan aktivitas penghambatan pertumbuhan terhadap larva $C$. pavonana.

Kata kunci: Ekstrak campuran, hama kubis, insektisida nabati, toksisitas

\section{PENDAHULUAN}

Tanaman kubis-kubisan (Brassicaceae) merupakan jenis tanaman sayuran yang banyak dibudidayakan dan dikonsumsi oleh masyarakat Indonesia. Produksi beberapa tanaman kubiskubisan pada tahun 2013-2014 mengalami penurunan seperti kubis 3.03\%, kol kembang 9.77\%, dan sawi 5.23\% (Kementan, 2015). Beberapa faktor yang menjadi penyebab penurunan produksi tersebut diantaranya menurunnya kesuburan lahan, berkurangnya luas lahan produksi, dan adanya serangan organisme pengganggu tanaman (OPT) (Sastrosiswojo et al., 2005). Ulat krop kubis Crocidolomia pavonana F. (Lepidoptera: Crambidae) merupakan salah satu hama penting pada pertanaman kubis-kubisan (Kalshoven, 1981) di berbagai daerah di Indonesia (Deptan, 2007). Menurut Bardjo et al. (2015) serangan C. pavonana dapat mengakibatkan kehilangan hasil produksi kubis hingga $49 \%$.

Pengendalian dengan menggunakan insektisida sintetik merupakan cara pengendalian hama kubis yang paling umum dilakukan oleh petani. Penggunaan insektisida sintetik dengan frekuensi tinggi dan secara terus-menerus dapat mengakibatkan dampak negatif seperti terjadinya resistensi dan resurjensi hama (Kau dan Cheng, 2001), berpengaruh pada kesehatan lingkungan dan residu pada produk pertanian yang berbahaya bagi konsumen (Dadang dan Prijono, 2008; Dharmaputra et al., 2016). Untuk itu, diperlukan upaya pengendalian lainnya yang aman bagi lingkungan, organisme bukan sasaran, dan diharapkan mampu mengurangi penggunaan insektisida sintetik yaitu menggunakan insektisida nabati yang terbuat dari bahan alami seperti tumbuhan. Kelebihan insektisida nabati dibandingkan insektisida sintetik antara lain mudah terurai di alam, umumnya aman terhadap organisme bukan sasaran (bersifat selektif), tidak cepat menimbulkan resistensi hama bila digunakan dalam bentuk ekstrak kasar, dapat dipadukan dengan teknik pengendalian hama lainnya, dan beberapa jenis insektisida nabati dapat disiapkan secara sederhana (Guleria dan Tiku,
2009). Indonesia memiliki keanekaragaman flora yang dapat dimanfaatkan sebagai sumber bahan insektisida nabati di antaranya belimbing wuluh (Averrhoa bilimbi, Oxalidaceae), srikaya (Annona squamosa, Annonaceae), dan kipait (Tithonia diversifolia, Asteraceae). Pada daun belimbing wuluh mengandung saponin, flavonoid, dan tanin yang mempunyai aktivitas antifeedant terhadap rayap tanah Coptotermes formosanus (Isoptera: Rhinotermitidae) (Ohmura et al., 2000), serta dapat mengendalikan Periplaneta americana (Blattodae: Blattidae) (Krisman et al., 2016), Anopeles aconitus (Diptera: Cullicidae), dan (Nopianti et al., 2008). Biji srikaya mengandung asetogenin yang terdiri atas squamosin dan asimisin yang bersifat racun perut pada Chrysomya bezziana (Diptera: Calliphoridae) (Wardhana et al., 2004) dan dapat mengendalikan wereng cokelat (Nilaparvata lugens) (Hemiptera: Delphacidae) (Prakash et al., 2008). Sementara itu, kipait mengandung senyawa-senyawa yang bersifat toksik terhadap Atta cephalotes (Hymenoptera: Myrmicinae) (Castano-Quintana et al., 2013), larva Chlosyne lacinia (Lepidoptera: Nymphalidae) (Ambrosio et al., 2008), larva C. bezziana (Wardhana dan Diana, 2014), dan hama gudang Callosobrochus maculatus (Coleoptera: Bruchidae) (Kolawole et al., 2014) seperti flavonoid, tanin, polifenol, dan triterpena (Kemenhut, 2010). Ekstrak daun A. bilimbi, biji A. squamosa dan bunga $T$. diversifolia mempunyai sifat insektisida akan tetapi potensi untuk mengendalikan larva C. pavonana belum banyak dipelajari, dan belum diketahui sifat insektisidanya. Tujuan penelitian ini untuk mempelajari aktivitas ekstrak daun A. bilimbi, biji A. squamosa, dan bunga $T$. diversifolia terhadap mortalitas dan penghambatan pertumbuhan larva $C$. pavonana.

\section{BAHAN DAN METODE}

Penelitian dilaksanakan di Laboratorium Fisiologi dan Toksikologi Serangga Departemen Proteksi Tanaman, Fakultas Pertanian, Institut Pertanian Bogor pada bulan Januari sampai September 2017. 


\section{Ekstraksi Bahan Tumbuhan}

Metode maserasi digunakan untuk mendapatkan ekstrak daun A. bilimbi, biji $A$. squamosa, dan bunga $T$. diversifolia yang mengacu pada Dadang dan Prijono (2011). Masing-masing bahan tumbuhan dipotongpotong lalu dikeringanginkan selama beberapa hari tanpa terpapar cahaya matahari. Potongan bahan tumbuhan yang telah keringanginkan dihaluskan menggunakan blender hingga menjadi serbuk. Sebanyak $200 \mathrm{~g}$ masingmasing serbuk bahan tumbuhan direndam dalam $2000 \mathrm{ml}$ metanol (1:10, w/v) selama 48 jam. Hasil rendaman disaring dengan kertas saring dan filtrat yang dihasilkan diuapkan menggunakan rotary evaporator pada suhu 50 ${ }^{0} \mathrm{C}$ dan tekanan 400-450 $\mathrm{mmHg}$ hingga diperoleh ekstrak kasar. Setiap ekstrak yang diperoleh dimasukkan ke dalam botol gelas gelap lalu disimpan dalam lemari pendingin pada suhu $\pm 4{ }^{\circ} \mathrm{C}$ hingga saat digunakan.

\section{Pemeliharaan dan Perbanyakan Serangga Uji}

Imago $C$. pavonana dikoleksi dari pertanaman kubis di Cisarua, Bogor. Selanjutnya imago yang dipelihara dan diperbanyak di Laboratorium Fisiologi dan Toksikologi Serangga, Departemen Proteksi Tanaman, Fakultas Pertanian IPB dan diberi pakan larutan madu $10 \%$ yang diserapkan pada kapas. Larva $C$. pavonana diberi pakan daun brokoli bebas pestisida yang diperoleh dari pertanian organik Bina Sarana Bhakti, Cisarua, Bogor.

\section{Uji Ekstrak Tunggal}

Pengujian ekstrak tunggal dilakukan dengan metode celup daun (Abizar dan Prijono, 2010). Setiap ekstrak diuji pada lima taraf konsentrasi yang ditentukan berdasarkan uji pendahuluan. Konsentrasi ekstrak daun $A$. bilimbi adalah $5 \%, 3.75 \%, 2.5 \%, 1.5 \%$, dan $0.75 \%$, ekstrak biji $A$. squamosa adalah $0.015 \%, \quad 0.01 \%, \quad 0.005 \%, \quad 0.0025 \%$, dan $0.00125 \%$, dan ekstrak bunga $T$. diversifolia adalah $5 \%, 2 \%, 1 \%, 0.5 \%$, dan $0.2 \%$. Pembuatan konsentrasi sediaan ekstrak dilakukan dengan metode pengenceran berseri (serial dilution). Masing-masing ekstrak dilarutkan dalam metanol dan pengemulsi tween-80 (5:1; v/v), kemudian diencerkan dengan menambahkan akuades sampai volume tertentu sesuai dengan konsentrasi uji yang dibutuhkan. Agar sediaan ekstrak tercampur secara merata, sediaan ekstrak diaduk menggunakan magnetic stirrer. Kontrol berupa akuades yang mengandung metanol $1 \%$ dan tween-80 0.2\%.

Potongan daun brokoli $(4 \mathrm{~cm} \times 4 \mathrm{~cm})$ dicelupkan satu persatu dalam sediaan ekstrak pada konsentrasi tertentu hingga basah merata lalu ditiriskan. Pada perlakuan kontrol daun dicelupkan dalam larutan kontrol. Dua potongan daun brokoli perlakuan dan kontrol diletakkan dalam cawan petri yang terpisah yang telah dialasi tisu, kemudian dimasukkan 15 larva $C$. pavonana instar I dengan lima ulangan. Setelah $2 \times 24$ jam, daun pakan perlakuan dan kontrol diganti dengan daun tanpa perlakuan. Data kematian larva dicatat pada saat 24-144 jam setelah perlakuan (JSP) dengan menghitung larva yang mati serta mengamati perubahan instar tiap serangga. Ekstrak yang memberikan aktivitas insektisida terbaik digunakan pada uji campuran. Data mortalitas yang diperoleh dianalisis dengan program POLO-PC (LeOra Software, 1987).

\section{Uji Campuran Ekstrak}

Hasil aktivitas insektisida nabati terbaik yang diperoleh pada pengujian ekstrak tunggal digunakan dalam uji campuran, yaitu ekstrak bunga $T$. diversifolia dan biji A. squamosa. Pengujian terdiri dari tiga perbandingan, yaitu 1:1, 1:2 dan 2:1 (w/w). Konsentrasi ekstrak yang digunakan untuk uji campuran ditentukan dari uji ekstrak tunggal yang dihitung dengan bantuan Microsoft Excel 2013, pada perbandingan $1: 1$ adalah $0.02 \%, 0.0062 \%$, $0.0032 \%, 0.0019 \%$, dan $0.00064 \%$, pada perbandingan $1: 2$ adalah $0.0123 \%, 0.0047 \%$, $0.0024 \%, 0.0014 \%$, dan $0.00048 \%$, dan pada perbandingan $2: 1$ adalah $0.024 \%, 0.0093 \%$, $0.0048 \%, 0.00285 \%$, dan $0.00095 \%$.

Metode pembuatan konsentrasi sediaan ekstrak, perlakuan, dan pengamatan pada uji campuran ekstrak sama seperti pada uji ekstrak tunggal. Data mortalitas pada 24-144 JSP diolah dengan analisis probit menggunakan program POLO-PC (LeOra Software, 1987) untuk menentukan hubungan konsentrasi mortalitas termasuk nilai $\mathrm{LC}_{50}$ dan $\mathrm{LC}_{95}$. Nilainilai LC/LD yang diperoleh digunakan untuk menentukan nilai indeks kombinasi (IK) yang selanjutnya digunakan untuk menentukan sifat 
interaksi campuran ekstrak yang dihitung menggunakan rumus Chou dan Talalay (1984): $\mathrm{IK}=\frac{\mathrm{LC}_{\mathrm{x}}^{1(\mathrm{~cm})}}{\mathrm{LC}_{\mathrm{x}}^{1}}+\frac{\mathrm{LC}_{\mathrm{x}}^{2(\mathrm{~cm})}}{\mathrm{LC}_{\mathrm{x}}^{2}}+\left(\frac{\mathrm{LC}_{\mathrm{x}}^{1(\mathrm{~cm})}}{\mathrm{LC}_{\mathrm{x}}^{1}} \mathrm{X} \frac{\mathrm{LC}_{\mathrm{x}}^{2(\mathrm{~cm})}}{\mathrm{LC}_{\mathrm{x}}^{2}}\right)$ dimana, $\mathrm{LC}_{\mathrm{x}}{ }^{1}$ dan $\mathrm{LC}_{\mathrm{x}}{ }^{2}$ merupakan nilai $\mathrm{LC}$ ekstrak tunggal. $\operatorname{LC}_{\mathrm{x}}{ }^{1}(\mathrm{~cm})$ dan $\operatorname{LC}_{\mathrm{x}}{ }^{2}(\mathrm{~cm})$ merupakan LC/LD campuran yang dikalikan proporsi ekstrak di dalam campuran yang mengakibatkan mortalitas (15-95\%). Kategori sifat interaksi campuran adalah sebagai berikut (Kosman dan Cohen, 1996): (1) bila IK < 0.5, komponen campuran bersifat sinergistik kuat; (2) bila IK $0.5 \leq$ IK $\leq 0.77$, komponen campuran bersifat sinergistik lemah; (3) bila $0.77<\mathrm{IK} \leq 1.43$, komponen campuran bersifat aditif; (4) bila IK > 1.43, komponen campuran bersifat antagonistik.

\section{Uji Penghambatan Pertumbuhan}

Pengujian penghambatan pertumbuhan C. pavonana dilakukan pada 15 larva instar I dengan mengaplikasikan ekstrak tumbuhan dengan berbagai konsentrasi yang telah ditentukan $\left(\mathrm{LC}_{5}, \mathrm{LC}_{30}\right.$, dan $\left.\mathrm{LC}_{50}\right)$ dan kontrol dengan metode pencelupan daun yang diulang sebanyak lima kali. Data dicatat pada saat 24144 JSP dengan mengamati perubahan instar tiap serangga. Data penghambatan pertumbuhan larva $C$. pavonana yang diperoleh dianalisis ANOVA-nya dengan Program SPSS (Statistical Product and Service Solution). Apabila hasilnya menunjukkan berbeda nyata maka dilakukan uji lanjutan menggunakan Duncan Multiple Range Test (DMRT) pada $\operatorname{tar} a f \alpha=0.05$.

\section{HASIL DAN PEMBAHASAN}

Mortalitas larva $C$. pavonana pada perlakuan ekstrak daun A. bilimbi, biji $A$. squamosa dan bunga $T$. diversifolia meningkat seiring dengan meningkatnya konsentrasi dan waktu pengamatan (Gambar 1). Mortalitas larva $C$. pavonana pada ketiga perlakuan mulai terjadi sejak 24 JSP yang mana ekstrak daun $A$. bilimbi, biji $A$. squamosa, dan bunga $T$. diversifolia menyebabkan mortalitas berturutturut sebesar 27\%, 19\%, dan $1 \%$ pada konsentrasi tertinggi. Pengamatan 48 JSP dan 72 JSP menunjukkan adanya peningkatan mortalitas pada perlakuan ekstrak daun $A$. bilimbi, biji $A$. squamosa, dan bunga $T$. diversifolia berturut-turut menjadi sebesar $31 \%$, 96\%, dan $4 \%$, dan $35 \%, 100 \%$, dan $15 \%$. Pengamatan 72 JSP ini, perlakuan konsentrasi tertinggi ekstrak biji $A$. squamosa sudah mampu menyebabkan $100 \%$ mortalitas. Pengamatan 96 JSP mortalitas meningkat pada perlakuan ekstrak daun A. bilimbi dan bunga $T$. diversifolia berturut-turut menjadi $41 \%$ dan $27 \%$. Sementara itu, pada pengamatan 120 JSP tidak terjadi peningkatan mortalitas larva $C$. pavonana pada ekstrak daun A. bilimbi. Hal tersebut kemungkinan senyawa aktif dalam tubuh larva telah mengalami penguraian (detoksifikasi) atau diekresikan bersama feses, sedangkan pada perlakuan ekstrak $T$. diversifolia masih menunjukkan peningkatan mortalitas menjadi $72 \%$, dan pada 144 JSP mortalitas meningkat mencapai 88\% (Gambar 1). Secara keseluruhan, aktivitas insektisida dari ketiga ekstrak tumbuhan yang diujikan secara tunggal menunjukkan bahwa ekstrak metanol biji A. squamosa mempunyai aktivitas insektisida yang paling baik sebagai racun perut. Hal ini ditunjukkan oleh nilai $\mathrm{LC}_{50}$ dan $\mathrm{LC}_{95}$ yang paling rendah dibandingkan dengan perlakuan ekstrak lainnya (Tabel 1).

Ekstrak bunga $T$. diversifolia dan biji $A$. squamosa pada uji toksisitas tunggal menunjukkan pengaruh mortalitas yang baik sehingga dilakukan pengujian campuran kedua ekstrak. Campuran ekstrak diuji dengan tiga perbandingan yaitu 1:1, 1:2 dan 2:1 (w/w). Menurut Dadang dan Prijono (2008), penggunaan insektisida nabati campuran yang bersifat sinergis mampu mengurangi penggunaan jumlah bahan baku dibandingkan dengan mengaplikasikan insektisida nabati secara tunggal. Selain itu, penggunaan campuran ekstrak dengan konsentrasi atau dosis yang rendah dapat mengurangi dampak negatif terhadap organisme bukan sasaran dan lingkungan. 
A. bilimbi

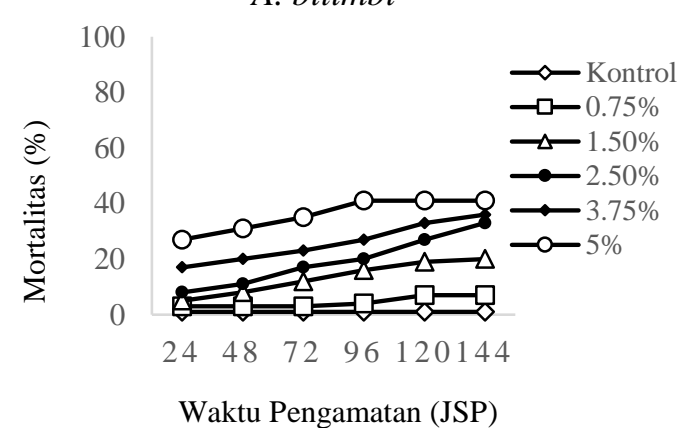

(a)

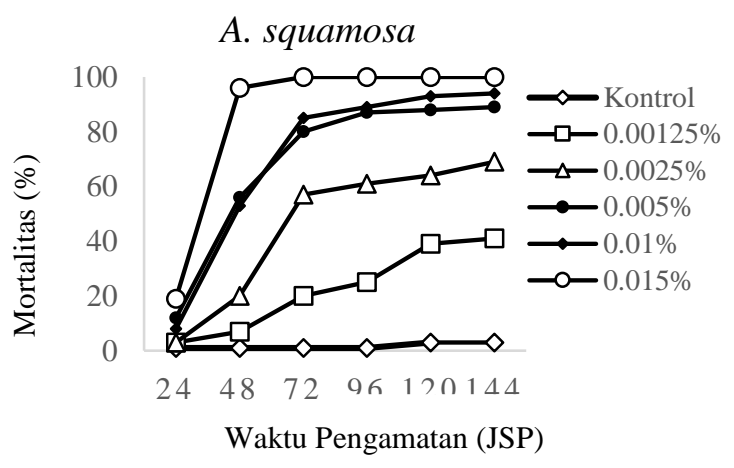

(b)

\section{T. diversifolia}

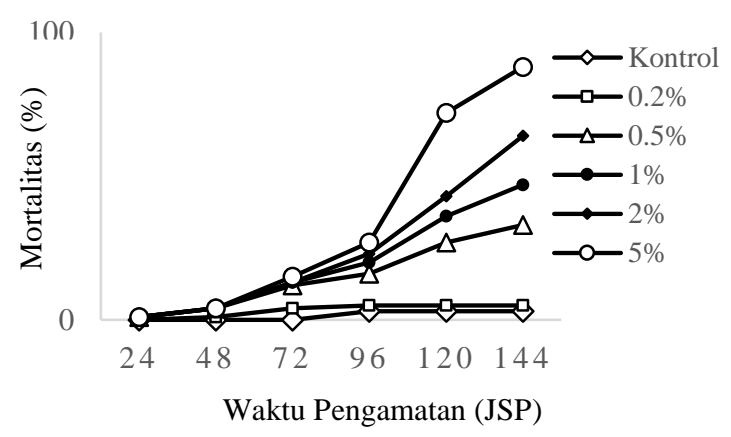

(c)

Gambar 1. Perkembangan mortalitas larva C. pavonana pada perlakuan tiga ekstrak tumbuhan yang diuji dengan metode residu pada daun.

Tabel 1. Penduga parameter persamaan regresi probit hubungan antara konsentrasi ekstrak dengan mortalitas larva C. pavonana pada pengamatan 144 jam

\begin{tabular}{lccccc}
\hline \multicolumn{1}{c}{ Ekstrak } & $a \pm \mathrm{GB}$ & $b \pm \mathrm{GB}$ & $\mathrm{LC}_{50}(\mathrm{SK} 95 \%)(\%)$ & $\mathrm{LC}_{95}(\mathrm{SK} 95 \%)(\%)$ \\
\hline \multicolumn{7}{c}{ Ekstrak Tunggal } \\
$\mathrm{Ab}$ & $3.79 \pm 0.14$ & $1.50 \pm 0.29$ & $6.39(4.69-11.55)$ & $79.32(30.92-607.14)$ \\
$\mathrm{As}$ & $11.55 \pm 0.69$ & $2.34 \pm 0.27$ & $0.002(0.001-0.002)$ & $0.008(0.01-0.01)$ \\
$\mathrm{Td}$ & $4.86 \pm 0.776 \mathrm{E}-01$ & $1.86 \pm 0.19$ & $1.19(0.82-1.75)$ & $9.10(4.79-34.06)$ \\
\multicolumn{7}{c}{ Campuran Ekstrak } \\
Td:As (1:1) & $6.28 \pm 0.35$ & $0.77 \pm 0.15$ & $0.021(0.01-0.06)$ & $2.95(0.48-149.16)$ \\
Td:As $(2: 1)$ & $6.53 \pm 0.45$ & $0.89 \pm 0.18$ & $0.019(0.01-0.07)$ & $1.33(0.23-74.18)$ \\
Td:As (1:2) & $5.83 \pm 0.45$ & $0.84 \pm 0.21$ & $0.102(0.04-1.35)$ & $9.43(0.88-9244.20)$ \\
\hline
\end{tabular}

Keterangan: $\mathrm{Ab}=($ Averrhoa bilimbi $), \mathrm{As}=($ Annona squamosa $), \mathrm{Td}=$ (Tithonia diversifolia $), a=$ (intersep regresi probit $)$, $b=($ kemiringan regresi probit $), \mathrm{GB}=($ galat baku $), \mathrm{SK}=($ selang kepercayaan $), \mathrm{LC}=($ lethal concentration $)$.

$\mathrm{LC}_{50}$ dan $\mathrm{LC}_{95}$ ekstrak $A$. squamosa secara terpisah nilainya lebih rendah dibandingkan dengan $\mathrm{LC}_{50}$ dan $\mathrm{LC}_{95}$ secara campuran (Tabel 1). Selain itu, pada pengamatan 144 JSP campuran ekstrak konsentrasi tertinggi perbandingan 1:1, 1:2, dan 2:1 (w/w) memiliki nilai mortalitas berturutturut sebesar 49\%, 41\%, dan 31\% (Gambar 2). Nilai tersebut lebih rendah dibandingkan dengan nilai mortalitas pada ekstrak $A$. squamosa secara terpisah, yaitu $100 \%$ (Gambar 1). Hal ini mencerminkan bahwa perlakuan secara terpisah lebih efektif terhadap mortalitas larva $C$. pavonana dibandingkan dengan hasil pada perlakuan campuran ekstrak bunga $T$. diversifolia dan A. squamosa. Berdasarkan nilai indeks kombinasi, sifat interaksi campuran ekstrak menunjukkan bahwa pada pengamatan 24 JSP, perbandingan 1:1 bersifat sinergis kuat pada $\mathrm{LC}_{50}$ dan $\mathrm{LC}_{95}$, sedangkan pada 
pengamatan lainnya bersifat antagonistik. Sementara itu perbandingan 1:2 dan 2:1 (w/w) bersifat antagonistik pada semua pengamatan (Tabel 2). Selain mengakibatkan kematian, perlakuan tiga ekstrak dapat memperpanjang lama pertumbuhan larva instar II C. pavonana yang bertahan hidup memasuki instar III dan/atau instar IV. Hasil penelitian ini menunjukkan bahwa ekstrak metanol daun $A$. bilimbi pada konsentrasi 5\% mampu memperlambat waktu pertumbuhan larva $C$. pavonana dari instar II ke instar IV (Tabel 2). Senyawa saponin yang terdapat dalam ekstrak daun A. bilimbi dapat mengganggu proses pergantian kulit (molting) pada serangga sehingga mampu memperlambat proses perkembangan larva (Syah dan Purwani, 2016).

Perlakuan ekstrak biji A. squamosa, konsentrasi rendah $0.0025 \%, 0.005 \%$ dan $0.01 \%$ mampu memberikan pengaruh terhadap lama pertumbuhan larva $C$. pavonana dari instar II ke III dan dari instar II ke IV (Tabel 3). Adanya pengaruh terhadap lama pertumbuhan larva menunjukkan bahwa ekstrak tanaman

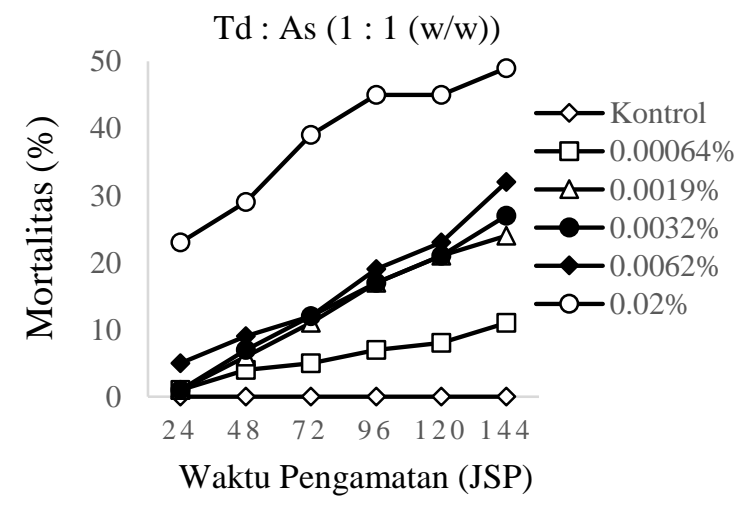

(a) yang termakan oleh serangga uji memberikan pengaruh buruk bagi kehidupan serangga tersebut. Menurut Santoso (2011), senyawa aktif biji $A$. squamosa mempengaruhi penyerapan makanan pada mesenteron dan hal ini dapat mengakibatkan penghambatan perkembangan larva uji. Lama waktu terbentuknya imago akan mempengaruhi proses perkembangan selanjutnya, seperti proses peneluran sehingga apabila terjadi perlambatan pembentukan imago, proses selanjutnyapun akan terlambat (Firmansyah, 2016). Perlakuan ekstrak bunga T. diversifolia pada semua konsentrasi tidak berpengaruh terhadap lama perkembangan larva dari instar II ke IV, tetapi berpengaruh terhadap lama perkembangan larva dari instar II ke III (Tabel 3). Hal ini disebabkan residu senyawa aktif sudah tidak terdapat dalam tubuh serangga uji karena diekresikan bersama feses, atau dapat juga disebabkan pada larva C. pavonana instar III dan IV sudah terjadi penguraian bahan aktif yang lebih tinggi pada tubuh serangga uji (Prijono dan Hassan, 1992).

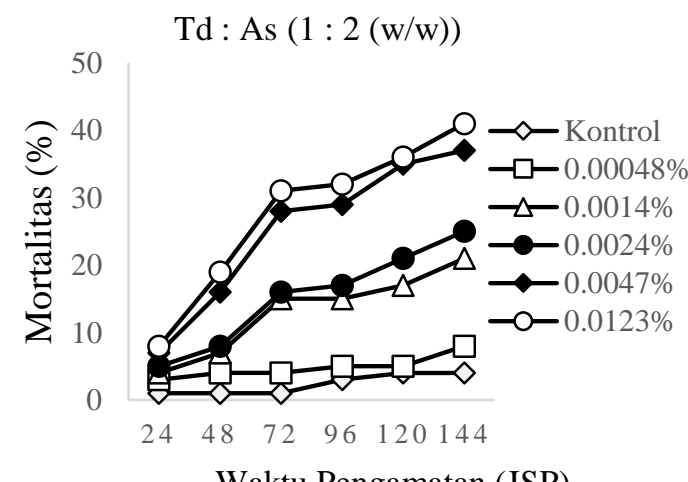

(b)

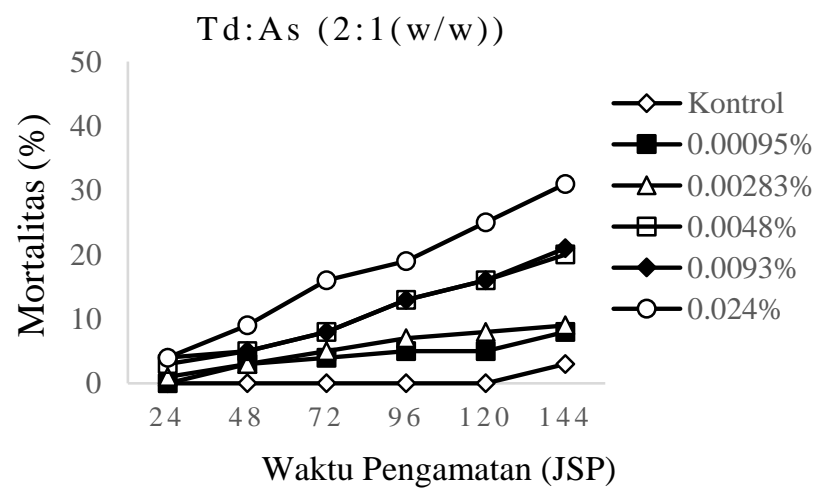

Gambar 2. Perkembangan mortalitas larva $C$. pavonana pada perlakuan campuran ekstrak $T$. diversifolia (Td) dan A. squamosa (As). 
Tabel 2. Sifat aktivitas campuran ekstrak T. diversifolia, dan A. squamosa terhadap larva C. pavonana

\begin{tabular}{|c|c|c|c|c|c|}
\hline \multirow{2}{*}{$\begin{array}{c}\text { Ekstrak } \\
(\mathrm{w} / \mathrm{w})\end{array}$} & \multirow{2}{*}{$\begin{array}{c}\text { Waktu } \\
\text { Pengamatan } \\
\text { (JSP) }\end{array}$} & \multicolumn{2}{|c|}{ Indeks Kombinasi } & \multicolumn{2}{|c|}{ Sifat Interaksi } \\
\hline & & $\mathrm{LC}_{50}$ & $\mathrm{LC}_{95}$ & $\mathrm{LC}_{50}$ & $\mathrm{LC}_{95}$ \\
\hline $\mathrm{Td}: \mathrm{As}$ & 24 & 0.42 & 0.45 & Sinergistik kuat & Sinergistik kuat \\
\hline \multirow[t]{5}{*}{$(1: 1)$} & 48 & 9.79 & 61.22 & Antagonistik & Antagonistik \\
\hline & 72 & 11.82 & 192.85 & Antagonistik & Antagonistik \\
\hline & 96 & 8.35 & 205.38 & Antagonistik & Antagonistik \\
\hline & 120 & 9.79 & 171.73 & Antagonistik & Antagonistik \\
\hline & 144 & 6.77 & 208.59 & Antagonistik & Antagonistik \\
\hline $\mathrm{Td}: \mathrm{As}$ & 24 & 77.00 & 8268.50 & Antagonistik & Antagonistik \\
\hline \multirow[t]{5}{*}{$(1: 2)$} & 48 & 23.32 & 880.46 & Antagonistik & Antagonistik \\
\hline & 72 & 10.31 & 192.64 & Antagonistik & Antagonistik \\
\hline & 96 & 7.73 & 107.89 & Antagonistik & Antagonistik \\
\hline & 120 & 9.50 & 110.69 & Antagonistik & Antagonistik \\
\hline & 144 & 7.91 & 116.14 & Antagonistik & Antagonistik \\
\hline $\mathrm{Td}: \mathrm{As}$ & 24 & 21.64 & 255.27 & Antagonistik & Antagonistik \\
\hline \multirow[t]{5}{*}{$(2: 1)$} & 48 & 1130.51 & 870258.94 & Antagonistik & Antagonistik \\
\hline & 72 & 266.26 & 62751.26 & Antagonistik & Antagonistik \\
\hline & 96 & 166.50 & 50784.54 & Antagonistik & Antagonistik \\
\hline & 120 & 45.95 & 5026.16 & Antagonistik & Antagonistik \\
\hline & 144 & 23.16 & 643.64 & Antagonistik & Antagonistik \\
\hline
\end{tabular}

Keterangan: $\mathrm{Td}=($ Tithonia diversifolia $), \mathrm{As}=($ Annona squamosa $), \mathrm{JSP}=$ jam setelah perlakuan, Sinergistik kuat $=$ indeks kombinasi $>0.5$; Antagonistik $=$ indeks kombinasi $>1.43$.

Perlakuan ekstrak biji A. squamosa, konsentrasi rendah $0.0025 \%, 0.005 \%$ dan $0.01 \%$ mampu memberikan pengaruh terhadap lama pertumbuhan larva $C$. pavonana dari instar II ke III dan dari instar II ke IV (Tabel 3). Adanya pengaruh terhadap lama pertumbuhan larva menunjukkan bahwa ekstrak tanaman yang termakan oleh serangga uji memberikan pengaruh buruk bagi kehidupan serangga tersebut. Menurut Santoso (2011), senyawa aktif biji A. squamosa mempengaruhi penyerapan makanan pada mesenteron dan hal ini dapat mengakibatkan penghambatan perkembangan larva uji. Lama waktu terbentuknya imago akan mempengaruhi proses perkembangan selanjutnya, seperti proses peneluran sehingga apabila terjadi perlambatan pembentukan imago, proses selanjutnyapun akan terlambat (Firmansyah, 2016). Perlakuan ekstrak bunga $T$. diversifolia pada semua konsentrasi tidak berpengaruh terhadap lama perkembangan larva dari instar II ke IV, tetapi berpengaruh terhadap lama perkembangan larva dari instar II ke III (Tabel 3).

Tabel 3. Lama perkembangan larva C. pavonana yang diberi perlakuan tiga ekstrak tanaman

\begin{tabular}{|c|c|c|c|c|}
\hline \multirow{2}{*}{ Ekstrak } & \multirow{2}{*}{\multicolumn{2}{|c|}{$\begin{array}{c}\text { Konsentrasi } \\
(\%)\end{array}$}} & \multicolumn{2}{|c|}{ Rata-rata Lama Perkembangan \pm SD (hari) } \\
\hline & & & Instar II ke III & Instar II ke IV \\
\hline Daun & Kontrol & & $2.2 \pm 0.1(74) \mathrm{a}$ & $3.8 \pm 0.2(73) a$ \\
\hline \multirow[t]{3}{*}{ Averrhoa bilimbi } & 0.75 & $\left(\mathrm{LC}_{5}\right)$ & $2.4 \pm 0.1(68) \mathrm{a}$ & $4.0 \pm 0.4(55) \mathrm{a}$ \\
\hline & 2.5 & $\left(\mathrm{LC}_{30}\right)$ & $2.4 \pm 0.6(55) \mathrm{a}$ & $4.1 \pm 0.3(42) \mathrm{a}$ \\
\hline & & $\left(\mathrm{LC}_{50}\right)$ & $3.3 \pm 0.3(42) b$ & $4.6 \pm 0.4(34) b$ \\
\hline Biji & Kontrol & & $2.0 \pm 0.0(74) \mathrm{a}$ & $3.7 \pm 0.4(73) \mathrm{a}$ \\
\hline \multirow[t]{3}{*}{ Annona squamosa } & 0.00125 & $\left(\mathrm{LC}_{5}\right)$ & $3.1 \pm 0.2(46) b$ & $4.0 \pm 0.2(44) \mathrm{ab}$ \\
\hline & 0.0025 & $\left(\mathrm{LC}_{30}\right)$ & $3.1 \pm 0.3(27) b$ & $4.3 \pm 0.4(23) b c$ \\
\hline & 0.005 & $\left(\mathrm{LC}_{50}\right)$ & $3.1 \pm 0.2$ ( 9) b & $4.8 \pm 0.4(8) c$ \\
\hline Bunga & Kontrol & & $2.0 \pm 0.0(75) \mathrm{a}$ & $3.8 \pm 0.2(73)$ \\
\hline \multirow[t]{3}{*}{ Tithonia diversifolia } & 0.2 & $\left(\mathrm{LC}_{5}\right)$ & $3.2 \pm 0.1(71) b$ & $3.8 \pm 0.3(70)$ \\
\hline & 0.5 & $\left(\mathrm{LC}_{30}\right)$ & $3.3 \pm 0.4(63) b$ & $3.8 \pm 0.8(42)$ \\
\hline & 1.0 & $\left(\mathrm{LC}_{50}\right)$ & $3.3 \pm 0.4(61) b$ & $3.8 \pm 0.5(28)$ \\
\hline
\end{tabular}

Keterangan: Angka-angka pada kolom yang sama yang diikuti huruf yang berbeda menunjukan perbedaan nyata pada uji jarak berganda Duncan (DMRT) $\alpha=5 \%$. SD (Standard deviasi), LC (lethal concentration). 


\section{KESIMPULAN}

Ekstrak biji A. squamosa menunjukkan aktivitas mortalitas paling tinggi dibandingkan ekstrak daun $A$. bilimbi dan bunga $T$. diversifolia dengan tingkat mortalitas $100 \%$ pada konsentrasi $0.015 \%$. Ekstrak bunga $T$. diversifolia dan biji $A$. squamosa secara terpisah lebih efektif terhadap mortalitas larva C. pavonana dibandingkan dengan campurannya. Setiap jenis ekstrak pada konsentrasi tertentu memiliki pengaruh yang berbeda terhadap lama perkembangan larva C. pavonana.

\section{DAFTAR PUSTAKA}

Abizar, M., D. Prijono. 2010. Aktivitas insektisida ekstrak daun dan biji Terphrosia vagelii J.D. Hooker (Leguminosae) dan ekstrak buah Piper cubeba L. (Piperaceae) terhadap larva Crocidolomia pavonana (F.) (Lepidoptera: Crambidae). JHPT Trop. 10(1): 1-12.

Ambrosio, S.R., Y. Oki, V.C. Heleno, J.S. Chaves, P.G. Nascimento, J.E. Lichston, M.G. Constantino, E.M. Varanda, F.B. Da Costa. 2008. Constituents of glandular trichomes of Tithonia diversifolia: relationships to herbivory and antifeedant activity. Phytochemistry. 69(10): 2052-2060.

Badjo, R., C.S. Rante, E.R.M. Meray, B.H. Assa, M.F. Dien. 2015. Serangan hama ulat krop (Crocidolomia pavonana F.) pada tanaman kubis (Brassica oleracea Var. Capitata I.) di Kelurahan Kakaskasen II, Kecamatan Tomohon Utara, Kota Tomohon. Jurnal Ilmiah Fakultas Pertanian Universitas Sam Ratulangi. 6(14): 29-37.

Castano-Quintana, K., J. Montoya-Lerma, C. Giraldo-Echeverri. 2013. Toxicity of foliage extracts of Thitonia diversifolia (Asteraceae) on Atta cephalotes (Hymenoptera: Myrmicinae) workers. Industrial Crops and Products. 44: 391395.
Chou, T.C., P. Talalay. 1984. Quantitative analysis of dose-effect relationships: the combined effects of multiple drugs or enzyme inhibitors. Adv Enzyme Regl. 22(3): 27-55.

Dadang, D. Prijono. 2008. Insektisida Nabati: Prinsip, Pemanfaatan dan Pengembangan. Departemen Proteksi tanaman. Fakultas Pertanian. Institut Pertanian Bogor.

Dadang, D. Prijono. 2011. Pengembangan teknologi formulasi insektisida nabati untuk mengendali hama sayuran dalam upaya menghasilkan produk sayuran sehat. JIPI. 6(2): 100-111.

Dharmaputra, O.S., L.I. Sudirman, M.M. Misnawati1. 2016. Potensi khamir sebagai agens pengendalian hayati Colletotrichum capsici, cendawan penyebab antraknosa pada buah cabai. J. Hort. Indonesia. 7(2): 91-101

[Deptan] Departemen Pertanian. 2007. Ulat krop (large cabbage heart caterpillar) Crocidolomia binotalis Zell. http://www. deptan.go.id/ditlinhorti/opt/kubis/ulat_kr op. [12 Agustus 2016].

Firmansyah, E. 2016. Ekstrak Thitonia diversifolia (Hemsl.) A. Gray sebagai insektisida nabati untuk pengendalian ulat daun kubis Plutella xylostella Linn. (Lepidoptera: Yponomeutidae). Tesis. Sekolah Pascasarjana Institut Pertanian Bogor. 21 hal.

Guleria, S., A.K. Tiku. 2009. Botanicals in pest management: Current status and future perspectives. p. 317-329. In R. Peshin, A.K. Dhawan (eds.). Integrated Pest Management: Innovation-Development Process. Springer Science. London.

Kalshoven, L.G.E. 1981. Pests of Crops in Indonesia. Van Hoeve. PT. Ikhtiar Baru. Jakarta.

Kau, C.H., E.Y. Cheng. 2001. Insecticides resistence in Plutella xylostella L. Jour Agric Res China. 50(4): 80-89. 
[Kemenhut] Kementerian Kehutanan. 2010. Pengenalan tumbuhan penghasil pestisida nabati dan pemanfaatannya secara tradisional. ISBN: 978-60298588-0-8. Kemenhut. Jakarta.

[Kementan] Kementerian Pertanian. 2015. Statistika Produksi Hortikultura 2014. Direktorat Jenderal Hortikultural. Kementerian Pertanian.

Kolawole, A.O., F.M. Olajuyigbe, J.O. Ajele, C.O. Adedire. 2014. Activity of the antioxidant defense system in a typical bioinsecticide and synthetic insecticidetreated cowpea storage beetle Callosobrochus maculatus F. (Coleoptera: Chrysomelidae). Int. J. Insect Sci. 6: 99108.

Kosman, E., Y. Cohen. 1996. Procedures for calculating and differentiating synergism and antagonism in action of fungicide mixtures. Phytopathology. 86(4): 12551264.

Krisman, Y., P. Ardiningsih, I. Syahbanu. 2016. Aktivitas bioinsektisida ekstrak daun belimbing wuluh (Averrhoa bilimbi) terhadap kecoak (Periplaneta americana). J. Kimia Khatulistiwa. 5(3): 1-7.

LeOra Software. 1987. POLO-PC User's Guide. LeOra Software. Petaluma. USA.

Nopianti, S., D. Astuti, S. Darnoto. 2008. Efektivitas buah belimbing wuluh (Averrhoa bilimbi L.) untuk membunuh larva nyamuk Anopheles aconitus instar III. Jurnal Kesehatan. 1(2): 103-114.

Ohmura, W., S. Doi, M. Aoyama, S. Ohara. 2000. Antifeedant activity of flavonoids and related compounds against the subterranean termite Coptotermes formosanus Shiraki. Journal of Wood Science. 46(2): 149-153.
Prakash, A., J. Rao, V. Nandagopal. 2008. Future of botanical pesticides in rice, wheat, pulses and vegetables pest management. J. Biopest. 1(2): 154-169.

Prijono, D., E. Hassan. 1992. Life cycle and demography of Crocidolomia pavonana Zeller (Lepidoptera: Pyralidae) on broccoli in the laboratory. Indon. J. Trop Agric. 4(1): 18-24.

Santoso, G.B. 2011. Aktivitas insektisida ekstrak biji srikaya (Annona squamosa L.) dari lokasi berbeda dan sinergismenya dengan ekstrak buah sirih hutan (Piper aduncum L.) terhadap larva Crocidolomia pavonana (F.) (Lepidoptera: Crambidae). Tesis. Sekolah Pascasarjana Institut Pertanian Bogor. $36 \mathrm{hlm}$.

Sastrosiswojo, S., T.S. Uhan, R. Sutarya. 2005. Penerapan Teknologi PHT pada Tanaman Kubis. Balai Penelitian Tanaman Sayuran. Bandung.

Syah, B.W., K.I. Purwani. 2016. Pengaruh ekstrak daun belimbing wuluh (Averrhoa bilimbi) terhadap mortalitas dan perkembangan larva Spodoptera litura. Jurnal Sains. 5(2): 23-28.

Wardhana, A.H., E. Widyastuti, A.W.A. Wirakmana, S. Muharsini, Darmono. 2004. Uji efikasi ekstrak heksan daging biji srikaya (Annona squamosa L.) terhadap pertumbuhan larva lalat Chrysomya bezziana secara in vitro. Jurnal Ilmu Ternak dan Veteriner. 9(4): 272-280.

Wardhana, A.H., N. Diana. 2014. Biolarvasidal activity of methanol extract of kipahit leaves (Tithonia diversifolia) against larvae of Chrysomya bezziana fly. Jurnal Ilmu Ternak dan Veteriner. 19(1):43-51. 